\title{
The impact of human resources policies and practices on organizational citizenship behaviors
}

\author{
Joel Adame Tinti ${ }^{\Omega}$ \\ Universidade Metodista de São Paulo \\ Luciano Venelli-Costa * \\ Universidade Metodista de São Paulo \\ Almir Martins Vieira ${ }^{\dagger}$ \\ Universidade Metodista de São Paulo \\ Alexandre Cappellozza $¥$ \\ Universidade Metodista de São Paulo
}

\begin{abstract}
This study aims to investigate how policies and practices in human resources (PPHR) impact organizational citizenship behaviors (OCB). The OCBs represent additional contributions from employees to their organizations and, somehow, individual actions expected in crisis scenario or changing time by managers. The theoretical basis contains Milkovich and Boudreau (1994), Dessler (2002), Demo et al. (2012), among others, to address PPHR and Handy (1978), Organ (1990) and Siqueira (2003) to OCB. We collect data from 156 employees of public, private and mixed companies located in the State of São Paulo. The results revealed significant impact from PPHR over OCB, and we evidence that only professional involvement exhibited significant relation. We also conclude that PPHR influence the dissemination of organizational image and creative suggestions from OCB factors. The results indicate suggestions where managers can act to extract, effectively, organizational citizenship behaviors from their employees.
\end{abstract}

Keywords: People management, Policies and practices in human resources, Organizational citizenship behavior.

\section{INTRODUCTION}

When hired by an organization, the worker carries with him/her the experiences acquired in organizations for which they have previously worked for throughout their professional career, as well as the knowledge acquired in educational institutions that they have attended and the skills developed throughout their career. However, although we do not intend to discuss the importance of both experiences and knowledge or skills, there is an emerging approach that translates into the need to study and apply the psychological capacities of human resources that can be measured, developed and managed to improve the performance of organizations (LUTHANS, 2002).

\author{
Corresponding author: \\ $\Omega$ Universidade Metodista de São Paulo \\ E-mail: joeltinti@yahoo.com.br \\ * Universidade Metodista de São Paulo \\ E-mail: Luciano.costa@metodista.br \\ † Universidade Metodista de São Paulo \\ E-mail: almir.vieira@gmail.com \\ ¥ Universidade Metodista de São Paulo \\ E-mail: alexandre.cappellozza@metodista.br \\ Received: 10/23/2015. \\ Revised: 05/31/2016. \\ Accepted: 08/17/2016. \\ Published Online: 08/01/2017.
}

DOI: http://dx.doi.org/10.15728/bbr.2017.14.6.6 
Authors like Legge (2006) and Armstrong (2009) affirm that the human resources area has assumed a strategic and relevant role in this process of raising awareness, creating and renewing their policies and practices, directing them more and more to the interests of their employees, considering that they are the main actors in achieving results, because they are producers of knowledge, innovation and organizational capacity.

Personnel management policies define the theoretical and practical framework built to enable the attainment of the organization's objectives, acting as guides of thought and action for the area of people management. The term "practices", in turn, is used in the sense of habit, routine or action, or when referring to activities that are components of routines (DEMO, 2012). On the other hand, the behavior of individuals in this process is fundamental, because it directly influences both their individual productivity and the productivity of their work group and, consequently, the organization.

This behavior, characterized by a set of spontaneous actions, which bring beneficial consequences to the organization as a whole, not included in the requirements of the formal role or in the formal schemes of rewards or sanctions provided by the organization, is termed as organizational citizenship behavior (SIQUEIRA, 2003).

Aware of the importance of this type of behavior to face global competitiveness and the need for continuous innovation, organizations are increasingly demanding organizational citizens (DUBRIN, 2003). Thus, the objective of this study is to analyze how policies and practices in human resources (PPHR) Impact organizational citizenship behaviors (OCB). Therefore, this article presents research with 156 workers, demonstrating the impact of PPHR on OCBs, by means of a quantitative study whose instrument of data collection was set up in a self-filling questionnaire. Since both PPHR and OCB are important elements in the discussion about managing people nowadays, this paper contributes to the broadening of the discussion about the theme, presenting results from a Brazilian context that, we believe, will be integrated into the current production in the academic scene and, at the same time, subsidize practices of people management.

\section{THEORETICAL FRAMEWORK}

This section contains references to Human Resources Policies and Practices (PPHR), Organizational Citizenship Behaviors (OCB) and recent research on the theme.

\section{POLICIES AND PRACTICES IN HUMAN RESOURCES}

Based on several authors, Oliveira and Oliveira (2011, p. 657) define HR management $(\mathrm{HRM})$ as an integrated set of planned and intended strategies, policies and practices for managing people in an organization; and HRM practices as the activities actually implemented and experienced by employees, and that can be objectively verified. The authors emphasize the integration that must exist between HR management practices and the internal and external contingencies of the organization.

Becker and Huselid (1998) termed as High Performance Work Systems (HPWS) when there is synergy between the whole system of people management and the strategic objectives. This coherence is important to understand the relationship between HR management and organizational performance.

While some research analyze the influence of each HR subsystem on the performance of the person or organization (OLIVEIRA; GUEIROS, 2004), others argue that it is the integration of subsystems that ensures better results (MACDUFFIE, 1995). Becker and Huselid (1998) argue that the uniqueness of the effective integration of a system into the strategy of a specific company is what guarantees the imitation difficulty and consequent competitive advantage, which occurs in High Performance Work Systems. 
BBR

14,6

638

Lepaket al.(2006) question research on the subject in terms of the international nomenclature diversity and try to clarify the terms. HR practices are at the lowest level of analysis and refer to isolated actions that organizations select in order to achieve some specific outcomes, such as behavioral interviews, employee socialization, $360^{\circ}$ evaluation, among others. HR policies are at a second level of analysis and represent an employeefocused program, which should influence the choices of HR Practices, for example, a performance payment policy should reflect on choices of practices such as profit sharing and variable income. An HR System operates at an even higher level and reflects a multipolicy program that must be internally consistent to achieve some global objectives. As an example, a high commitment system should have more diversified development policies combined with performance based payment, to encourage employee commitment and maximize their contributions toward organizational performance.

Although HR systems can match organizational results and reflect in a greater competitive advantage, Lepaket al.(2006) question the difficulty of operationalizing this construct in research, in terms of the range of definitions that appear in the literature and the difficulty of evaluating the integration between these and their respective policies and practices.

For this reason, this research is focused on HR practices and their effects on employees' perceptions. Dessler (2002) listed out these practices necessary to manage people at work, specifically in the aspects related to hiring, training, evaluation, remuneration and the provision of a good and secure environment for company employees. For the author, there were five main policies and practices that constituted people management in organizations by the HR area: recruitment and selection, training and development, remuneration, performance appraisal and working conditions.

For Demo (2012), human resources policies and practices needed to contribute to the greater well-being of people, allowing them greater personal and professional fulfillment. In addition to the policies and practices defined by Dessler (2002), began considering the "involvement" policy in the group of the main PPHR.

In Brazil, PPHR are studied in their relations with several constructs, such as organizational culture (OSÓRIO, 2009), organizational engagement (RAMOS, 2010), affective commitment (FERREIRA, 2012; MARTINS, 2015), organizational commitment (SOUZA; MARQUES, 2014), intentions to leave the organization (SANTOS, 2012), turnover (M. P. SILVA, 2013), identification of collective competences (F. M. SILVA, 2013), and diversity management (MACCALI;KUABARA; TAKAHASHIet al.,2015).

International research has linked PPHR with successful projects (KHAN; RASHEED, 2015); absenteeism, intention to remain in the organization, organizational citizenship behaviors and affective commitment (KEHOE; WRIGHT, 2013); engagement, organizational citizenship behaviors and intentions to leave the organization (ALFES et al., 2013).

Due to the difficulty of evaluating the integration of human resources policies and practices (LEPAK et al, 2006), this research proposes not only to evaluate PPHR as a single construct, but also the relation of each dimension - or subsystem - on organizational citizenship behaviors, seeking to identify which policy has a greater or lesser impact on the worker's behavior. Thus, the six dimensions analyzed are: recruitment and selection; involvement; training and development; work conditions; performance and competency assessment; and remuneration and incentives.

Among the studies found on the topic of Policies and Practices in Human Resources, several that are published both in Brazil and abroad (OLIVEIRA; DEMO, 2014; JESUS; ROWE, 2015;FERREIRA et al., 2015) use the SPPHR - Scale of Policies and Practices in Human Resources, developed and validated by Demo (2012), which contemplates the six dimensions being studied. 
For Demo (2012), recruitment and selection policies and practices are defined as an organization proposal to seek out employees, stimulate them to apply and select them, seeking to harmonize the person's competencies with characteristics and demands of the organization. The involvement policy is an articulated proposal of the organization to create an affective bond with its collaborators, contributing to their well-being, in terms of recognition, relationship, participation and communication. The training and development policy includes the provision to employees of the systematic acquisition of skills and the encouragement of continuous learning and knowledge production.

Demo (2012) brought together in a single dimension the policies focused on safety and benefits, and named it as working conditions policy. The author's definition of this policy is an articulated proposal of the organization to provide employees with good working conditions in terms of benefits, health, safety and technology. The performance and competency evaluation policy involves assessing the performance and skills of workers, subsidizing decisions about promotions, career planning and development. The author also grouped the issues of compensation and incentives, encompassing rewards on performance and employee competencies in terms of remuneration and incentives.

Given this conceptual field presented and the objectives of the research, the PPHR scale elaborated by Demo (2012) is an adequate instrument to meet the objectives of this study.

\section{ORGANIZATIONAL CITIZENSHIP BEHAVIORS (OCB)}

The organization is a system of consciously coordinated personal activities or forces. Thus, collective work translates into the need for common objectives, a spirit of cooperation and, above all, the establishment of norms and regulations. Likewise, the existence of an organized activity is only possible if there is good will, spontaneity or personal disposition for cooperation (BARNARD, 1938).

While spontaneity for cooperation at work seems to be a fundamental characteristic of the worker, it is up to the organization the difficult and necessary task of awakening in its participants the desire not only to join, but also to remain in the organization, so that it can survive in a stable way (KATZ; KAHN, 1978). Thereby, a redimensioning of the vision of the working man/woman appears, as we can observe that the individuals' abilities and potentialities to contribute spontaneously to established goals within the organization are able to overcome the barriers of formality and prescription, as well as going beyond what is established to them as a duty (ORGAN, 1990).

For the individual's spontaneous behavior, Katz and Kahn (1978) used, for the first time, the term organizational citizen. For them, the individual had rights and duties and was able to donate to the organization. These authors found in the concept of citizenship the appropriate term to refer to the voluntary behavior of the individual in the organization.

It was from the approaches of authors as Katz and Kahn (1978) and the search for organizational effectiveness that the interest in the organizational citizenship theme began to gain a new dimension. However, if the formal labor contracts required compliance with schedules, rules and established what the worker had as a duty, as well as what the organization would grant them by right, the need to identify how organizational citizenship would be understood between organization and collaborator was raised, since voluntary acts would not be subordinated to pre-established clauses and rules.

It was especially in the 1980s that the focus of the analysis was directed to aspects that were poorly cultivated, i.e., for how the worker behaved in a team, how one developed their skills, whether or not they did their best in performing their work, whether or not the organization was defended in situations that required such behavior or if extraordinary tasks were performed in relation to those established in their job description (ORGAN, 1990). 
BBR

14,6

640

The concept of giving in favor of the organization, advocated by Katz and Kahn (1978) was gradually replaced by another: that of exchange, generated by the principle of reciprocity.

Whereas Organ (1990) defined organizational citizenship as the manifestation of voluntary benevolent behaviors, which transcended formal obligations and possible guarantees of contractual rewards, Siqueira (1995) assumed the concept of exchange, arguing that this type of behavior manifested itself in the psychological relations of social exchange between employees and the organization to which they belonged.

Organ (1977) provides a detailed analysis of the various criticisms that the definition of Organizational Citizenship Behaviors has received since the first attempt to present it in the study by Bateman and Organ (1983), And ends up questioning the voluntariness and what would be beyond the obligation, since obligations in the workplace are not restricted to the description of the work position. The author also questions the issue of rewards, since the "contextual performance" (ORGAN, 1977, p. 90) includes voluntary acts that go beyond formal expectations, including helping co-workers, the obedience of implicit rules and the defense of organizational objectives. Finally, the author prefers to simplify Organizational Citizenship Behaviors (OCB) as those who are part of the job, but not specifically the task. He summarizes that performance at work has two parts - OCB and tasks; and that they differ in degree of importance and assurance of reward, but the OCB cannot be considered external to the organizational context or without reward.

In Brazil, one of the researchers who has most devoted to the theme is Siqueira (1995, 2003 , 2014). The author presents the construct as cognitive, within the norm of reciprocity, i.e., The worker personifies the organization and places it in debt when they carry out obligatory acts, in the expectation of becoming a creditor and, in the future, receiving some reward that compensates the debt of the organization towards them. This definition is consistent with discussions by Organ (1990), since he does not consider OCB as acts totally voluntary or without reward.

Although Costa and Andrade (2013) point out that the scales by Williams and Anderson (1991) and by Podsakoff et al. (1990) have been the most used internationally, Siqueira (1995) was the first to validate an Organizational Citizenship Behavior Scale (OCBS) ins Brazil, containing five dimensions: disclosure of organizational image; creative suggestions; protection of the organization's assets; professional preparation and cooperation with coworkers. In 2011, in order to improve the accuracy of its measurements it was enhanced, reducing it to three dimensions: creative suggestions; disclosure of organizational image; and cooperation with colleagues (BASTOS; SIQUEIRA; GOMES, 2014). This scale contemplates the discussion of the definition proposed by Organ (1990) and, as it was already validated and in use in Brazil (CANTAL; BORGES-ANDRADE; PORTO, 2015), it will also be used in this study.

Among the three dimensions, Creative Suggestions (CS) are actions that contain innovative proposals for the organization, contemplating the presentation of solutions to the boss for problems found in the work environment (BASTOS et al., 2014). For Porto and Tamayo (2003), innovative and spontaneous behavior is necessary for the organization, since it constitutes a performance above the paper requirements for the achievement of the organizational functions.

The dimension Organizational Image Disclosure (OID) is conceptualized as a set of actions in the external environment that disclose the qualities of the organization (BASTOS et al., 2014). This dimension involves voluntarily promoting the image of the organization outside the work environment, defending it against external threats and contributing to its good reputation (PORTO; TAMAYO, 2003).

Finally, the dimension Cooperation with Colleagues (CC) includes the actions of offering help and support to co-workers in the organization (BASTOS et al., 2014). It contemplates voluntary gestures of help to a colleague when they have work-related problems; the 
demonstration of the worker's ability to deal with interpersonal conflicts, facilitating the relationship between individuals, in order to maintain a harmonious working environment; encouragement; strengthening the professional fulfillment and development of co-workers and the display of prevention and planning gestures, in order to avoid problems. Such behaviors are described by Podsakoff et al. (2000) and Organ, Podsakoff and Mackenzie (2006).

\section{RELATIONSHIP BETWEEN POLICIES AND PRACTICES IN HUMAN RESOURCES AND ORGANIZATIONAL CITIZENSHIP BEHAVIORS}

There are several studies that relate Organizational Citizenship Behaviors and other constructs of organizational behavior such as perception of justice, perception of support, job satisfaction or organizational commitment (PAVALACHE-ILIE, 2014; RUBIN; BRODY, 2011; TAGHINEZHAD et al., 2015); characteristics of the individual, such as personality (KUMAR; BAKHSHI; RANI, 2009); leadership (PODSAKOFFet al., 1990), among others. However, our focus in this article is to present the studies that relate Policies and Practices in Human Resources and Organizational Citizenship Behaviors.

Lam, Chen and Takeuchi (2009) Studied how PPHR affect OCB in a Japanese joint venture, located in China. The authors outlined three objectives: to explore how PPHR affected OCB, how OCB impact on the employees' turnover intention and whether OCB functioned as a mediating variable between PPHR and turnover intention. The studied PPHR were recruitment and selection, remuneration, training and development and performance evaluation. The results of the quantitative research indicated that HR policies significantly impacted individuals' organizational citizenship behaviors, and that training and development policies and involvement were the ones that caused the greatest impact. They also concluded that OCB had a direct impact on turnover intention. Employees who had intended to leave the company did not act as organizational citizens, responding to the second objective of the researchers. Finally, regarding the mediation of OCB between PPHR and turnover intention, the researchers concluded that OCB is a partial mediator between the relation of PPHR with turnover intention.

Another study, conducted by Snape and Redman (2010) investigated the impact of PPHR on OCB among English workers. One of the objectives of the study is to analyze whether organizational support mediated the relationship between PPHR and OCB. The quantitative results showed that when workers perceive that the organizational support goes beyond the work performed by them, the established PPHR by organizations positively affect OCB. However, if the support is modest and restricted to the obligations of the company to perform the tasks, even by maintaining the same PPHR, organizational citizenship behaviors are adversely affected.

Tang and Tang (2012) investigated the impact of PPHR on OCBs in Taiwanese hotels. The authors considered organizational environment and justice to be mediating variables. The results showed that, when the organizational environment is pleasant, organizational citizenship behaviors tend to manifest themselves in greater intensity. However, for the environment to be favorable to the manifestation of OCB, the PPHR must be transparent and perceived as fair by employees. Otherwise, the environment is negatively affected and OCB tends not to manifest, harming all the efficiency and organizational competitiveness.

Estivalete et al. (2013) researched the international scientific production between 2002 and 2012 on OCB and concluded that, Of the 118 empirical studies that deal with OCB as an independent variable, 22 of them deal with the relationship between OCB and organizational justice, 17 with the relationship of OCB and leadership, 12 between OCB 
BBR

14,6

642

and performance at work, 12 between OCB and job satisfaction, and 10 between OCB and organizational commitment.

Given the need for organizations to maintain PPHR linked to organizational strategies, awakening and maintaining OCB among its collaborators, it is important to carry out this study to identify the impact of the six PPHR on OCB in the organizational context, allowing managers to better manage practices to improve results, since OCB has shown to have positive relationships with results of organizational interest, such as improved team performance (PODSAKOFF; AHEARNE; MACKENZIE, 1997), increased sales (BENZECRY; PIRES, 2009), among others (ORGAN; PODSAKOFF; MACKENZIE, 2006). Thus, the theoretical model was assumed based on the relationship between human resources policies and practices and organizational citizenship behaviors, according to the conceptual field presented in the previous sections.

\section{METHODOLOGICAL PROCEDURES}

To reach the objectives proposed in this study, we adopted a quantitative approach. The data collection instrument is a self-completion questionnaire composed of the Human Resources Policy and Practice Scale, structured and validated by Demo (2012), composed of 40 items, distributed in six factors, which measures the employees' perception of policies and practices in human resources management (HRM) and the Organizational Citizenship Behavior Scale, improved by Bastos, Siqueira and Gomes (2014), composed of 14 items, distributed in three factors, which measures the worker's organizational citizenship behavior.

The participants' choice was done by convenience. Tabachnick and Fidell (2001) indicate that the appropriate sample size estimate is calculated by the formula $\mathrm{N} \geq 50+8 . \mathrm{k}$, where " $\mathrm{k}$ " is the number of independent variables. Thus, since the independent variables that will be studied add up to six (recruitment and selection /R\&S; involvement/IN; training and development /T\&D; work conditions /WC; performance evaluation/PE; and remuneration/ R\&R), this study must have at least 98 respondents.

In this study, we collected data from workers from public companies, private and mixed, located in the state of São Paulo. 156 workers participated in the study, responding to the questionnaire. The data collection was carried out in a space provided by the researchers (3 rooms, with a desk for respondents and a desk for a researcher), so that the participants received a printed version of the questionnaire and, before filling it out, they were guided about the research objectives. After the answers were completed, each participant inserted the questionnaire in an envelope left on the table. These procedures have contributed to ensuring that all questionnaires were answered in full. At the end of the questionnaire, we collected data on the characterization of the participants, such as gender, age, marital status, schooling, length of time at work, type of company where they work, whether they occupy a leading position now and how the respondent performs most of their work (table 1).

The impact tests were analyzed by Structural Equation Model estimated by the PLS method in the SmartPLS 2.0 M3 software. We performed statistical analyzes through the Path Coefficient and $\mathrm{R}^{2}$, Bootstrap Test and Student's $t$ test.

\section{RESULTS}

Table 2 reports the number of items, the range of responses, the means, the standard deviations, the coefficients of variation and the Cronbach's alpha of the factors that make up the PPHR scale. Most of the coefficients of variation presented values above $30 \%$ and all the values found for Cronbach's Alpha were higher than 0.70, thus indicating, high reliability and variability required for this type of research.

In Table 2, we can observe that the OID and the CS dimensions presented average coefficients variation, But the CC dimension presented low coefficient of variation (less 
than 0.20), revealing that the respondents' perceptions regarding this dimension are similar. All the values found for the Cronbach's alpha were higher than 0.70 indicating, therefore, high reliability.

To perform the necessary calculations for validation of the structural model of this study, we used the SmartPLS software version 2.0 M3 (RINGLE; WENDE; BECKER, 2014) and to examine the convergent and discriminant validity of the constructs used in the structural model, we performed the Factorial Analysis (HAIR JR. et al., 2005). The results of the factorial loads are shown in Table 3.

In the result of the Factor Analysis, all the constructs present indicators with high loads in their latent variables and low loads in the other latent variables, indicating a reasonable discriminant and convergent validity (CHIN, 2000). The only indicators that did not present values higher than 0.70 were N16, N29 and N30, being excluded from the analyzes.

According to Fornell and Larcker (1981), the value of the Average Variance Extracted of each construct is expected to be greater than 0.5 . In the values presented in table 4 , we observe that all the values of the average variance extracted from the constructs were above the satisfactory values. The composite reliability describes the degree to which the indicators represent the latent construct in common and have an acceptable reference value of 0.70 . The commonalities obtained and that represent the total amount of variance that the construct shares with the other constructs are also satisfactory with results above 0.5 (HAIR JR. et al., 2013).

The verification of the discriminant validity between the constructs can be analyzed by the estimated correlation matrix and the square root of the average variance extracted

Table 1. Demographics of respondents $(n=156)$

\begin{tabular}{|c|c|c|c|c|c|c|c|}
\hline Variables & Levels & $f$ & $\%$ & Limits & Mean & Medium & SD \\
\hline \multirow{2}{*}{ Gender } & Male & 16 & 10.389 .7 & & & & \\
\hline & Female & 140 & & & & & \\
\hline Age (in years) & & & & $19-46$ & 26.17 & & 5.882 \\
\hline \multirow{3}{*}{ Marital status } & Not married & 115 & 73.7 & & & & \\
\hline & Married & 32 & 20.5 & & & & \\
\hline & Others & 9 & 5.8 & & & & \\
\hline \multirow{7}{*}{ Education } & Elementary school & 3 & 1.9 & & & & \\
\hline & High school & 80 & 51.3 & & & & \\
\hline & Higher educ. incomplete & 64 & 41.0 & & & & \\
\hline & Higher educ. complete & 9 & 5.8 & & & & \\
\hline & Specialization & 0 & 0 & & & & \\
\hline & Maters & 0 & 0 & & & & \\
\hline & Doctorate degree & 0 & 0 & & & & \\
\hline Length of time in the company (in years) & & & & $0-15$ & & 2.00 & \\
\hline \multirow{4}{*}{ Type of company } & Public & 13 & 8.3 & & & & \\
\hline & Private & 141 & 90.4 & & & & \\
\hline & Mixed & 2 & 1.3 & & & & \\
\hline & NGOs & 0 & 0 & & & & \\
\hline \multirow{2}{*}{$\begin{array}{l}\text { Do you currently hold a management } \\
\text { position? }\end{array}$} & No & 130 & 83.3 & & & & \\
\hline & Yes & 26 & 16.7 & & & & \\
\hline \multirow{3}{*}{ How do you do most of your work? } & Alone & 75 & 48.1 & & & & \\
\hline & With someone else & 34 & 21.8 & & & & \\
\hline & In a Group & 47 & 30.1 & & & & \\
\hline
\end{tabular}


BBR

14,6

644

Table 2. Descriptive analysis of the dimensions that make up the SPPHR and OCBS

\begin{tabular}{lcccccc}
\hline Dimension & Items & Scale of answers & Mean & Standard Deviation & Coefficient of variation & Cronbach's Alpha \\
\hline IMAG_DISC & 5 & $1-5$ & 3.13 & 1.09 & $35.0 \%$ & 0.91 \\
COOP_COL & 4 & $1-5$ & 4.17 & 0.74 & $18.0 \%$ & 0.78 \\
INVOLV & 12 & $1-5$ & 2.97 & 0.96 & $32.5 \%$ & 0.91 \\
TRAIN\&DEV & 6 & $1-5$ & 2.84 & 1.09 & $38.4 \%$ & 0.87 \\
WORK_COND & 6 & $1-5$ & 3.12 & 0.97 & $31.2 \%$ & 0.74 \\
PE.EVA\&COMP & 5 & $1-5$ & 2.52 & 1.18 & $37.0 \%$ & 0.91 \\
REM\&REW & 5 & $1-5$ & 2.64 & 1.04 & $39.4 \%$ & 0.82 \\
CREAT_SUG & 5 & $1-5$ & 3.05 & 1.01 & $33.0 \%$ & 0.90 \\
\hline
\end{tabular}

Source: Elaborated by the authors

from the constructs (AVE). Table 5 presents the values that are considered adequate for the discriminant validity, according to Fornell and Larcker (1981).

For the analysis of the model in question, we performed a PPHR impact test on OCB. The results allowed to affirm that the PPHR dimension explains $31.7 \%$ of OCB, since $\mathrm{R}^{2}$ explains how much the dependent variable (OCB) is impacted by the independent variable (PPHR). The factors that have greater relevance in PPHR are those that present greater explanation $\left(\mathrm{R}^{2}\right)$ of the variance of PPHR. The $\mathrm{R}^{2}$ is the value presented in the center of the circles of each latent variable in the PLS. In order of greater relevance, the factors are: Involvement $\left(\mathrm{R}^{2}=0.808\right)$, Training and Development $\left(\mathrm{R}^{2}=0.761\right)$, Performance Evaluation $\left(\mathrm{R}^{2}=0.734\right)$; Remuneration and Rewards $\left(\mathrm{R}^{2}=0.680\right)$; Work conditions $\left(\mathrm{R}^{2}=0.588\right)$ And Recruitment and Selection $\left(\mathrm{R}^{2}=0.420\right)$.

To confirm the significance, we used the Bootstrap test to measure Student's $t$ between several random samples of the cases. Student's $t$ found for the relationship (PPHR and OCB) was $t=9.859 ; \mathrm{p}<0.001$, therefore significant. Thus, we can state that the PPHR defined by the organization affect how the worker will behave in situations in which there are no rules, regulations or guidelines that describe the behavior that the organization expects from them.

Aiming to improve the analyzes, we carried out impact tests to identify $\beta$ and the $\mathrm{R}^{2}$ of the six policies that make up PPHR on OCB as a whole.

When directly tested, the PPRH factors, in simultaneous action, impacted in $42.1 \%$ the organizational citizenship behaviors of the respondents. The path coefficient $(\beta)$ highlights that the politics that present the most impactful result in the organizational citizenship behaviors is Involvement $(\beta=0.285 ; p<0.01)$, confirming the results that showed the impact of this policy on the PPHR set. The other policies presented the following results: Remuneration $(\beta=0.148 ; p>0.05)$, Training and Development $(\beta=0.142 ; p>0.05)$, Work conditions $(\beta=0.096 ; p>0.05)$, Performance evaluation $(\beta=0.090 ; p>0.05)$ and Recruitment and selection $(\beta=0.012 ; p>0.05)$.

According to the results, only the Involvement policy has a significant relationship with OCB $(t=2.741 ; \mathrm{p}<0.01)$. This means that, for respondents, policies and practices that demonstrate concern of the organization with the well-being of the employee, as well as those that seek the integration of employees such as social gatherings, sporting and social events and promote recognition for the work done, they are able to positively interfere with the organizational citizenship of employees.

The reward policy presented $t=1.497$ when we investigated its relation with OCB, therefore it was not significant. The result reveals that remunerations compatible with the position held or the level of schooling, or linked to results obtained in work performance do not impact organizational citizenship significantly. Moreover, for respondents, offers of commissions, gratifications or bonuses have a reasonable impact on employee attitudes that reveal organizational citizenship. 


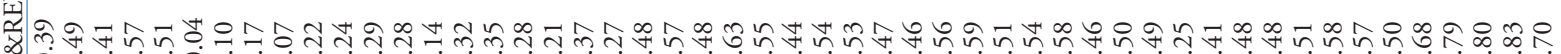
200000,000000000000000000000000000000000000000000000

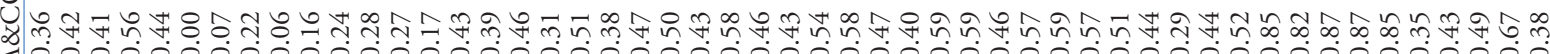

m

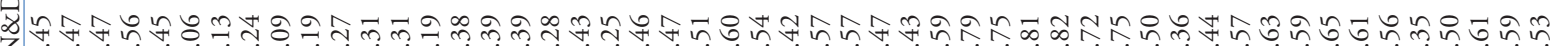
至

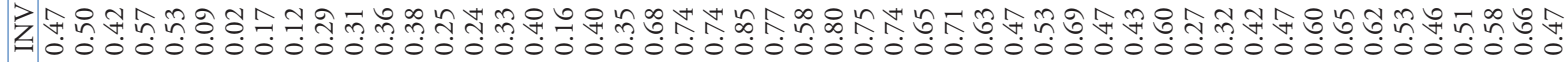

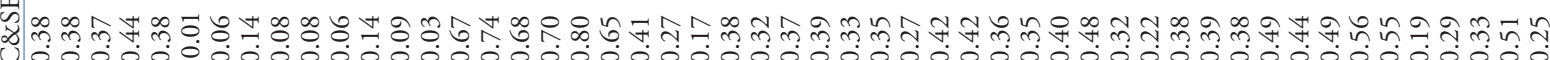
됟

Sִ

फ़े 空

\section{ชิ}

ㄱำ ठี

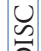

ज्ञ

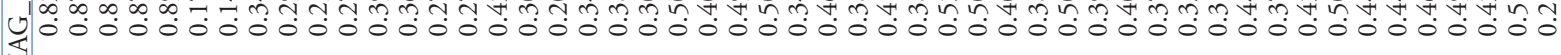

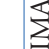

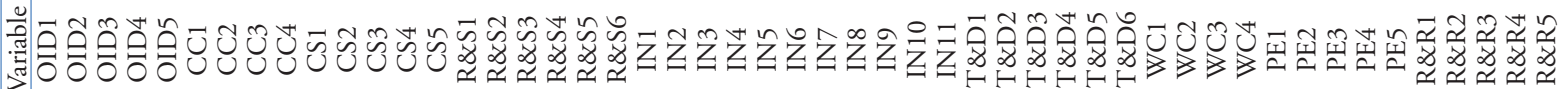

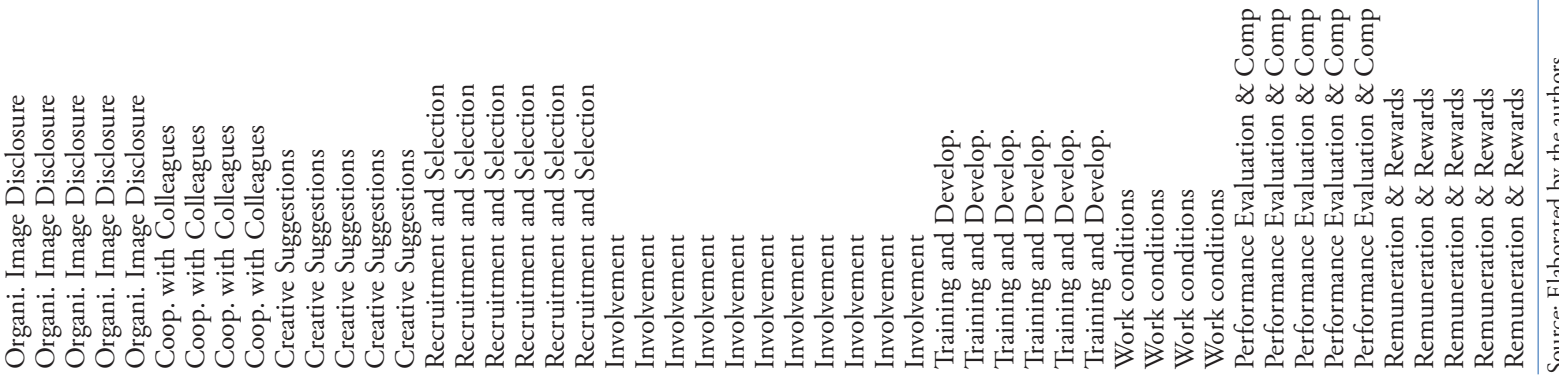


Table 4. Average Extracted Variance, Reliability and Commonality

\begin{tabular}{lccc}
\hline Constructs & Average Variance Extracted from constructs & Composite Reliability & Commonality \\
\hline Performance Evaluation \&Comp & 0.73 & 0.93 & 0.73 \\
Work Conditions & 0.54 & 0.83 & 0.54 \\
Cooperation with Colleagues & 0.61 & 0.86 & 0.61 \\
Org. Image Disclosure & 0.74 & 0.80 & 0.74 \\
Involvement & 0.51 & 0.93 & 0.51 \\
Recruitment and Selection & 0.51 & 0.86 & 0.51 \\
Remuneration \& Rewards & 0.58 & 0.87 & 0.58 \\
Creative Suggestions & 0.71 & 0.92 & 0.71 \\
Training and Development & 0.60 & 0.90 & 0.60 \\
\hline
\end{tabular}

Source: Elaborated by the authors

Table 5. Correlation matrix and square root of the average variance extracted

\begin{tabular}{|c|c|c|c|c|c|c|c|c|c|}
\hline & $\begin{array}{l}\text { PE.EVA } \\
\text { COMP }\end{array}$ & WORKCOND & COOPCOL & $\begin{array}{l}\text { IMAG } \\
\text { DISC }\end{array}$ & INV & $\begin{array}{c}\text { REC\& } \\
\text { SEL }\end{array}$ & $\begin{array}{l}\text { REM\& } \\
\text { REW }\end{array}$ & $\begin{array}{c}\text { CREAT } \\
\text { SUG }\end{array}$ & $\begin{array}{c}\text { TRAIN } \\
\text { DEV }\end{array}$ \\
\hline PE.EVA\&COMP & 0.85 & & & & & & & & \\
\hline WORK_COND & 0.58 & 0.73 & & & & & & & \\
\hline COOP_COL & 0.13 & 0.10 & 0.78 & & & & & & \\
\hline IMAG_DISC & 0.51 & 0.49 & 0.32 & 0.86 & & & & & \\
\hline INVOLV & 0.68 & 0.56 & 0.14 & 0.58 & 0.73 & & & & \\
\hline REC\&SEL & 0.59 & 0.45 & 0.10 & 0.46 & 0.46 & 0.71 & & & \\
\hline REM\&REW & 0.62 & 0.57 & 0.11 & 0.55 & 0.71 & 0.43 & 0.76 & & \\
\hline CREAT_SUG & 0.27 & 0.16 & 0.42 & 0.37 & 0.38 & 0.10 & 0.28 & 0.84 & \\
\hline TRAIN\&DEV & 0.71 & 0.65 & 0.18 & 0.56 & 0.70 & 0.50 & 0.69 & 0.31 & 0.77 \\
\hline
\end{tabular}

When investigating the impact of the training and development policy on OCB, we obtained $t=1.182$, that is, not significant. For the workers participating in this study, practices and policies aimed at the development of skills such as participation in congresses or trainings, granting full or partial scholarships and stimulating learning and knowledge production are factors with little impact on their behaviors that manifest organizational citizenship.

On the other hand, the Recruitment and Selection policy presented $t=1.059$ and was therefore considered not to be significant. Therefore, we can affirm that the dissemination of the recruitment processes and the way in which the selection tests are conducted and applied by the organization are not significant when it comes to stimulating organizational citizenship behavior among workers.

This study also revealed that the Work Conditions policy has no impact on OCB $(t=$ 0.968). In view of the results, we can state that accident prevention plans, occupational safety, facilities and physical conditions (such as temperature, lighting, ventilation and noise) and ergonomic conditions to perform the work are not factors of significant impact on workers' organizational citizenship behaviors.

Similarly, the Performance Evaluation policy has no impact on organizational citizenship behaviors neither. The test presented $t=0.102$, proving to be insignificant. For respondents, the process of evaluating performance in all its context (subsidy for promotions, criteria established by the organization, forms of achievement and dissemination of results to employees) do not impact on the manifestation of organizational citizenship behaviors.

In addition, we performed the PPHR impact tests on the factors that compose OCB, aiming to identify $\beta$ and the $\mathrm{R}^{2}$. We were able to identify, through the path and determination coefficients, that human resources policies and practices impact on cooperation with 
colleagues at $3.4 \%$. Among the factors that compose OCB, cooperation with colleagues is what shows the lowest impact of PPHR. Between the variable PPHR and OID (organizational image disclosure) we found $\beta=0.655$ and $\mathrm{R}^{2}=0.429$ and between PPHR and CS (creative suggestions) the values $\beta=0.354$ and $\mathrm{R}^{2}=0.126$, values well above the dimension $\mathrm{CC}$ (cooperation with colleagues): $\beta=0.185$ and $\mathrm{R}^{2}=0.034$. This means that behaviors aimed at disseminating the organizational image and creative suggestions within the work environment are, for this sample, those most affected by the policies and practices in human resources defined by the organization.

With the Student's t test, by using the Bootstrap method, we were able to identify the level of significance of the results (appendix). The results showed that the impacts were significant in the case of the OID and CS dimensions. We were able to observe that the greatest impact caused by the variable PPHR in the factors of OCB falls on OID (organizational image disclosure) with $t=12.649 ; \mathrm{p}<0.001$. The results revealed that HR policies and practices significantly impact workers' behavior when it is necessary for them to defend the organization where they work in the face of external criticism.

The impact caused by PPHR on CS (creative suggestions) is also significant, even if to a lesser extent). The results, through the Bootstrap test, pointed to $t=4.980 ; \mathrm{p}<0.001$. For the participants, the presentation of suggestions or creative ideas that bring solutions to the problems found in the task or in the work sector are significantly impacted by the human resources policies and practices established by the organization where they work. On the other hand, the cooperation dimension with colleagues presented the lowest results $(t=1.805)$, therefore not significant, when we analyze the impact suffered by PPHR. Offering support to colleagues in the face of personal problems, as well as helping the less experienced, who present difficulties or who are confused at work, do not have a significant impact on the organization's PPHR.

Table 6 shows the results according to the impact of the variable PPHR on the OCB variable (as well as its components), in addition to the impact of the component factors of the PPHR variable on the OCB variable.

In view of the verified results, we could observe that, in analyzing the impact of the PPHR variable on the OCB variable, both the coefficient of determination and the Student's $t$ test revealed that it is significant $\left(\mathrm{R}^{2}=0.317\right.$ and $\left.t=9.859\right)$. When investigating the impact that the six human resources policies have on organizational citizenship behaviors, we noted that there was a coherent relationship between the results of the path coefficient and Student's t, revealing that only the Involvement policy significantly impacts the behaviors of organizational citizenship $(\beta=0.285$ and $t=2.741)$. Finally, the results of the tests carried out showed that both the coefficient of determination and Student's $t$ test point the organizational image disclosure as the OCB factor that receives the greatest impact of human resources policies and practices $\left(\mathrm{R}^{2}=0.429\right.$ and $\left.t=12.649\right)$, followed by the creative suggestions factor $\left(\mathrm{R}^{2}=0.126\right.$ and $\left.t=4.980\right)$.

\section{FINAL CONSIDERATIONS}

Studies on organizational citizenship behaviors have gained considerable attention in recent years worldwide. Managers have shown an interest in the fact that human resource lies in the competitive differential they seek for the organizations where they work. And the behavior of this resource is fundamental in order for competitiveness and organizational effectiveness to be achieved.

Doing something more, accomplishing what is not foreseen, proving to be an altruistic collaborator and exceeding obligations, are attitudes that have been demanded by organizations among their workers. These are the so-called organizational citizenship behaviors. 
BBR

14,6

648

Table 6. Relationship between variables and results of $\beta, \mathrm{R}^{2}$ and Student's $t$

\begin{tabular}{|c|c|c|c|c|}
\hline & Related variables & $\beta$ & $\mathrm{R}^{2}$ & Student's $t$ \\
\hline Impact of the PPHR variable on the OCB variable & PPHR -> OCB & 0.563 & 0.317 & $9.859^{* * *}$ \\
\hline \multirow{6}{*}{ Impact of the factors that make up the PPHR variable over the OCB variable } & $\mathrm{R} \& S \rightarrow \mathrm{OCB}$ & 0.012 & \multirow{6}{*}{0.421} & 1.059 \\
\hline & $\mathrm{IN} \rightarrow \mathrm{OCB}$ & 0.285 & & $2.741^{* *}$ \\
\hline & $\mathrm{T} \& \mathrm{D} \rightarrow \mathrm{OCB}$ & 0.142 & & 1.182 \\
\hline & WC $\rightarrow$ OCB & 0.096 & & 0.968 \\
\hline & $\mathrm{PE} \rightarrow \mathrm{OCB}$ & 0.09 & & 0.102 \\
\hline & $\mathrm{R} \& \mathrm{R} \rightarrow \mathrm{OCB}$ & 0.148 & & 1.497 \\
\hline \multirow{3}{*}{ Impact of the PPHR variable on the factors that compose the OCB variable } & PPHR $->$ CC & 0.185 & 0.034 & 1.805 \\
\hline & PPHR -> OID & 0.655 & 0.429 & $12.649^{* * *}$ \\
\hline & PPHR $->$ CS & 0.354 & 0.126 & $4.980^{* * *}$ \\
\hline
\end{tabular}

*** $\mathrm{p}<0.001 ;{ }^{* *} \mathrm{p}<0.01$

Source: Elaborated by the authors

The purpose of this research is to analyze how human resources policies and practices (PPHR) impact organizational citizenship behaviors (OCB). It allowed us to investigate how policies directed to the intra-role behavior of the individual impact on their extra-role behavior.

Therefore, three analyzes were defined. The first concerned the impact of PPHR on OCB. The results showed that human resources policies and practices significantly impact the manifestation of voluntary acts that reveal organizational citizenship. These results are similar to those found in research conducted in England, China and Taiwan (LAM; CHEN; TAKEUCHI, 2009; SNAPE; REDMAN, 2010; TANG; TANG, 2012). In them, the results showed that the PPHR in organizations of those countries impact OCB, leading workers to diminish their turnover intention and improving their perception of the environment, justice and organizational support.

In the theoretical field, a particular contribution of this study is to show the impact that the policies that make up PPHR, individually, exert on OCB. The results show that only the Involvement policy has a significant relation with OCB. The other policies did not have a significant impact on organizational citizenship behaviors. As only the Involvement policy has a significant relationship with OCB $(t=2.741 ; \mathrm{p}<0.01)$, but the impact of all policies together accounted for $42.1 \%$ of $\mathrm{OCB}$, it is clear that behavior beyond contractual obligations (extra-role) are highly dependent on policies and practices that demonstrate concern by the organization with the well-being of the employee, besides those that seek the integration of the collaborators and those that promote the acknowledgement for an accomplished task. For respondents, having autonomy and participating in the decisionmaking process of the company is important and causes OCB to manifest itself with greater intensity. Further within the context of involvement, it is significant for the manifestation of organizational citizenship by employees that the company fosters a climate of trust and cooperation among employees, managers and co-workers.

Finally, the third analysis of the study considers the impact exerted by PPHR on the factors that compose OCB. The results show that PPHR has a significant impact on the dimensions organizational image disclosure and creative suggestions, respectively. On the other hand, the impact on cooperation with colleagues is not significant. The fact that the first two variables refer directly to the organization, its image and its processes, and as it is an employer of the individual, it can explain the reason for such significant impacts. On the other hand, the dimension of cooperation with colleagues refers much more to feelings of friendship, camaraderie and companionship, not dealing with the direct relation between 
individual and organization, but between individuals. These results reveal two behaviors desired by organizations, but not linked to formal job descriptions, which are: the employee defending the organization when someone external criticizes it; and the suggestions that the employee gives freely to the organization, helping to solve problems in other areas, which ultimately promote the improvement of organizational processes and innovation in products or services.

In the practical field, for HR managers, this article contributes by demonstrating the importance of involvement policies in the context of other HR policies. By its intangible and subjective character - concern of the organization with the well-being of the employee - , it is an element that needs to be constantly evaluated, asking employees if they have this perception of the involvement policies. This monitoring allows punctual actions (such as events and awards) to be evaluated and reinforced, or suppressed. If the organization wants the worker to behave in a manner not foreseen in its formal structure of work, characterized by informality and voluntariness - such as the behaviors of organizational citizenship -, it needs to know that these are reinforced by voluntary actions of the organization, such as the Involvement policies.

This study did not intend to diagnose the institutions where the research participants work. Due to differences in organizational contexts, there may be differences in results. We suggest for more studies to be carried out in specific contexts, identified by a specific organizational culture or a specific economic sector, in order to confirm the results.

\section{REFERENCES}

ALBUQUERQUE, L. O papel estratégico de RH.Tese de livre-docência, FEA-USP, 1988.

ALFES, K.;SHANTZ, A.;TRUSS, C.;SOANE, E. The link between perceived human resource management practices, engagement and employee behavior: a moderated mediation model. The international journal of human resource management, v. 24, n. 2, p. 330-351, 2013.

ARAÚJO, L. C. G. Gestão de pessoas: Estratégia e Integração organizacional. São Paulo: Atlas, 2006

ARMSTRONG, M. Armstrong's handbook of Human Resource Management practice. 11 ${ }^{\mathrm{a}}$.ed. London: Kogan Page, 2009.

BARNARD, C.I. The Functions of the executive. Cambridge, MA: Harvard University Press, 1938.

BASTOS, A.V.B.; SIQUEIRA, M.M.M; GOMES, A.C.P. Cidadania Organizacional. In: SIQUEIRA, M.M.M. (Org.)Novas medidas do comportamento organizacional: ferramentas de diagnóstico e de gestão,cap. 6,p. 79-103. Porto Alegre:Artmed, 2014.

BATEMAN, T. S.; ORGAN, D. W. Job Satisfaction and the Good Soldier: The Relationship between Affect and Employee "Citizenship". The Academy of Management Journal, v. 26, n. 4, p. 587-595, 1983.

BECKER, B. E.; HUSELID, M. A. High Performance Work Systems and Firm Performance: a Synthesis of Research and Managerial Implications. Personnel and Human Resources Management, v. 16, p. 53-101, 1998.

BENZECRY, D. F.; PIRES, H. M. Comportamento De Cidadania Organizacional (CCO) E Desempenho Em Vendas. Encontro Nacional de Engenharia de Produção. Anais...Salvador: ABEPRO, 2009

CHIN, W. W. Partial Least Square for researchers: a overview and presentation of recent advances using the PLS approach, 2000.

CANTAL, C.; BORGES-ANDRADE, J. E.; PORTO, J. B. Cooperação, comportamentos proativos ou simplesmente cidadania organizacional? Uma revisão da produção nacional na área. Revista Psicologia Organizações e Trabalho, v. 15, n. 3, p. 286-297, 2015.

COSTA, V. F.; ANDRADE, T. Comportamentos de cidadania organizacional: caracterização da produção científica internacional no período de 2002 a 2012. RAM. Revista de Administração Mackenzie, v. 16, n. 2, p. 45-71, 2013.

DEMO, G. Desenvolvimento e validação da escala de percepção de políticas de gestão de pessoas (EPPGP). Revista de Administração Mackenzie, v. 9, n. 6, 2008.

DEMO, G. Políticas de Gestão de Pessoas nas organizações: Estado da arte, Produção Nacional, Agenda de Pesquisa, Medidas e Estudos Relacionais. São Paulo: Atlas, 2012. 
BBR

14,6

DEMO, G.; MARTINS, P. de R.; ROURE, P. Políticas de gestão de pessoas, comprometimento organizacional e satisfação no trabalho na Livraria Cultura. Revista Alcance - Eletrônica, v. 20, n. 2, p. 237-254, abr./jun. 2013.

DESSLER, G. Administração de Recursos Humanos. 2a.ed. São Paulo: Prentice Hall, 2002.

DUBRIN, A.J. Fundamentos do comportamento organizacional. São Paulo: Pioneira Thomson Learning, 2003.

EISENBERGER, R.; HUNTINGTON, R.; HUTCHISON, S.; SOWA, D. Perceived Organizational Support. JournalofAppliedPsychology, v. 71, n. 3, p. 500-507, 1986.

ESTIVALETE, V.F.B.; COSTA, V.F.; ANDRADE, T.; LOBLER, M.L.; TANSCHEIT, F.D. Comportamento de cidadania organizacional: caracterização da produção científica internacional no período de 2002 a 2012. In: XXXVII Encontro da Associação de Pós-Graduação e Pesquisa em Administração, 37, 2013, Rio de Janeiro. Anais...Rio de Janeiro: ANPAD, 2013.

FERREIRA, M.C.O.; SILVA, J.G.; BIZARRIAS, F.S.; CARVALHO, J. B.; SOUZA, F. M. S.; FRANÇA, M. H.; GONÇALVES, M. S. Políticas e práticas de gestão de pessoas e suas relações com o absenteísmo: desafios ao desenvolvimento sustentável. Labor \& Engenho, v.9, n.3, p.87-97, Campinas/SP, 2015.

FISCHER, A.L. A constituição do modelo competitivo de gestão de pessoas no Brasil: um estudo sobre as empresas consideradas exemplares. Tese de Doutorado, Universidade de São Paulo, 1998.

FORNELL, C.; LARCKER, D. F. Evaluating structural equation models with unobservable variables and measurement error. Journal of Marketing Research, v.18, p.39-50, 1981.

HAIR, JR., J. F.; ANDERSON, R. E.; TATHAM, R. L.; BLACK, W. C. AnáliseMultivariada de Dados. 5. ed. Porto Alegre: Bookman, 2005.

HAIR, JR., J. F.; HULT, G. T. M.; RINGLE, C. M.; SARSTEDT, M. A Primer on Partial Least Squares Structural Equation Modeling (PLS-SEM). Thousand Oaks: SAGE Publications, 2013.

HIPÓLITO, J.A.M.; REIS, G.G. As pessoas na organização. 16ª.ed. São Paulo: Editora Gente, 2002.

JANSSEN, O.; HUANG, X. Us and Me: Team Identification and Individual Differentiation as Complementary Drivers of Team Members' Citizenship and Creative Behaviors. Journalof Management, v. 34, n. 1, p. 69-88, 2008.

JESUS, R. G; ROWE, D. E. O. Percepção de políticas de gestão de pessoas e comprometimento organizacional:o papel mediador da percepção de justiça organizacional. Tourism and Management Studies. v.11, n.2, p. 211-218, 2015.

KATZ, D.; KAHN, R.L. The social psychology of organizations. $2^{\mathrm{a}}$.ed. New York: John Wiley and sons, 1978.

KEHOE, R. R.; WRIGHT, P. M. The impact of high-performance human resource practices on employees' attitudes and behaviors. Journal of Management, v. 39, n. 2, p. 366-391, 2013.

KHAN, A. S.; RASHEED, F. Human resource management practices and project success, a moderating role of Islamic Work Ethics in Pakistani project-based organizations. International Journal of Project Management, v. 33, n. 2, p. 435-445, 2015.

KUMAR, K.; BAKHSHI, A.; RANI, E. Linking the "big five" personality domains to organizationalcitizenship behavior. InternationalJournalofPsychologicalStudies, v. 1, n. 2, p. 73-81, 2009.

LACOMBE, F. Recursos Humanos: Princípios e Tendências. São Paulo: Saraiva, 2005.

LAM, W.; CHEN, Z.; TAKEUCHI, N. Perceived human resource management practices and intention to leave of employees: the mediating role of organizational citizenship behavior in a Sino-Japanese joint venture. The International Journal of Human Resource Management, v.20, n.11, p.2250-2270, November 2009.

LEGGE, K. Human resource management. In: ACKROYD, S.; BATT, R.; THOMPSON, P.; TOLBERT, P. S. (Eds).The Oxford handbook of work and organization. New York: Oxford University Press, 2006, pp.220-241.

LEPAK, D. P.; LIAO, H.; CHUNG, Y.; HARDEN, E. E. A Conceptual Review of Human Resource Management Systems in Strategic Human Resource Management Research. Research in Personnel and Human Resource Management, v. 25, n. 06, p. 217-271, 2006.

LUTHANS, F.Positive Organizational Behavior: Developing and Managing Psychological Strenghts.Nova York: Academyof Management Executive, 2002.

MACCALI, N.; KUABARA, P. S. S.; TAKAHASHI, A. R. W.; ROGLIO, K. D.; BOEHS, S. T. M. As práticas de recursos humanos para a gestão da diversidade: a inclusão de deficientes intelectuais em uma federação pública do Brasil. RAM, Rev. Adm. Mackenzie, Abr 2015, vol.16, no.2, p.157-187.

MACDUFFIE, J. Human resource bundles and manufacturing performance: Organizational logic and flexible production systems in the world auto industry. Industrial and Labor Relations Review, v. 48, n. 2, p. 197-221, 1995. 
MARRAS, J.P. Administração de Recursos Humanos: do operacional ao estratégico. São Paulo: Futura, $3^{\mathrm{a}}$.ed., 2000.

MILKOVICH, G.T.; BOUDREAU, J.W. Human Resource Management. McGraw-Hill HigherEducation, 1994.

OLIVEIRA, A. M. B.; OLIVEIRA, A. J. Gestão de Recursos Humanos: uma metanálise de seus efeitos sobre desempenho organizacional. Revista de Administração Contemporânea - RAC, v. 15, n. 4, p. 650-669, 2011.

OLIVEIRA, L. M. B.; GUEIROS, M. G. Clientes internos satisfeitos com as práticas de RH conduzem à satisfação dos clientes externos: Um estudo no setor hoteleiro.XXVIII Encontro Nacional dos Programas de Pós-Graduação em Administração. Anais...Curitiba/PR: ANPAD, 2004

OLIVEIRA, M. M.; DEMO, G. Bem-estar no trabalho na Disney: o papel das políticas e práticas de gestão de pessoas. Gestão e Saúde, v. 4, n. 3, p. pag. 3605-3632, 2014.

ORGAN, D.W. The motivational basis of organizational citizenship behavior. In: STAW, B. M.;CUMMINGS, L. L. (Eds). Research in organizational behavior, v.12. Greenwich, CT: Jai Press, 1990, p.43-72.

ORGAN, D. W. Organizational Citizenship Behavior: it's construct clean-up time. Human Performance, v. 10, n. 2, 85-97, 1997.

ORGAN, D.W.; PODSAKOFF, P.M.; MACKENZIE, S.B. Organizational Citizenship Behavior. Its nature, antecedents and consequences. London: Sage Publication, 2006.

PAVALACHE-ILIE, M. Organizational citizenship behaviour, work satisfaction and employee's personality. Procedia - Social and Behavioral Sciences, v. 127, n. 1983, p. 489-493, 2014.

PODSAKOFF, P.M.; MACKENZIE, S.B.; PAINE, J.B.; BACHRACH, D.G. Organizational citizenship behaviors: a critical review of the theoretical and empirical literature and suggestions for future research. Journalof Management, v.26, n.3, 513-563, 2000.

PODSAKOFF, P. M.; MACKENZIE, S. B.; MOORMAN, S. B.;FETTER, R. Transformational leader behaviors and their effects on followers' trust in leader, satisfaction, and organizational citizenship behaviors. The Leadership Quarterly, v. 1, n. 2, p. 107-142, 1990.

PODSAKOFF, P. M.; AHEARNE, M.; MACKENZIE, S. B. Organizational citizenship behavior and the quantity and quality of work group performance. The Journal of applied psychology, v. 82, n. 2, p. 262-70, 1997.

PORTO, J.; TAMAYO, A. Desenvolvimento e validação da escala de valores do trabalho - EVT. Psicologia: Teoria e Pesquisa, v.19, n.2, p.145-152, 2003.

RIBEIRO, A.L. Gestão de Pessoas. 2 ${ }^{\text {a }}$ ed. São Paulo: Saraiva, 2012.

RINGLE, C. M.; WENDE, S.; BECKER, J. M. SmartPLS. Hamburg: SmartPLS,2014. Disponívelem: <www. smartpls.com> (Acessoem 17.12.2014).

RUBIN, B. A.; BRODY, C. J. Operationalizing Management Citizenship Behavior and Testing Its Impact on Employee Commitment, Satisfaction, and Mental Health. Work and occupations, v. 38, n. 4, p. 465-499, 2011.

SILVA, F. M. As Práticas de Gestão de Recursos Humanos e o processo de identificação de competências coletivas: um estudo de caso na área de gestão de pessoas do centro administrativo do Sicredi. Tese de doutorado. Escola de Administração. Rio Grande do Sul: UFRGS, 2013.

SILVA, M. P. Relação das Práticas de Gestão de Recursos Humanos com turnover: um estudo com empresas do norte do Paraná. Dissertação de mestrado. Faculdade de Economia, Administração e Contabilidade de Ribeirão Preto. USP, 2013.

SIQUEIRA, M.M.M. Antecedentes de comportamentos de cidadania organizacional: a análise de um modelo pós-cognitivo. Tese de Doutorado. Brasília: Instituto de Psicologia da Universidade de Brasília, 1995.

SIQUEIRA, M.M.M. Proposição e análise de um modelo para comportamentos de cidadania organizacional. São Paulo: Revista de Administração Contemporânea, edição especial, p.165-184, 2003.

SIQUEIRA, M.M.M. (org.)Novas medidas do comportamento organizacional: ferramentas de diagnóstico e de gestão. Porto Alegre:Artmed, 2014, pp. 79-103.

SNAPE, E.; REDMAN, T. HRM Practices, Organizational Citizenship Behavior, and Performance: A MultiLevel Analysis.Journalof Management Studies, v.47, n.7, p.1219-1247, November, 2010

SOUZA, E. P.; MARQUES, A. L. Práticas de recursos humanos e comprometimento organizacional: considerações teóricas sobre como o comprometimento pode ser tratado nas organizações. VIII Encontro de Estudos Organizacionais da ANPAD - EnEO. Anais... Gramado/RS : ANPAD, 2014.

TABACHNICK, B.G.; FIDELL, L.S. Using multivariate statistics, 4a.ed. Boston: Allyn and Bacon, 2001.

TAGHINEZHAD, F. et al. Antecedents of organizational citizenship behavior among Iranian nurses: a multicenter study. BMC, v. 8, n. 547, p. 1-9, 2015. 
BBR

14,6

652
TANG, T.W.; TANG, Y.Y. Promoting service-oriented organizational citizenship behaviors in hotels: The role of high-performance human resource practices and organizational social climates. International Journal of Hospitality Management, v.31, p. 885-895, 2012.

WILLIAMS, L. J.; ANDERSON, S. E. Job satisfaction and organizational commitment as predictorsof organizational citizenship and in-role behaviors. Journalof Management, v. 17, n.3, p. 601-617, 1991. 
Appendix. Factorial loads of the measurement model and statistics (Student's $t$ )

\begin{tabular}{|c|c|c|c|c|c|}
\hline & Mean & Standard Deviation & Statistics T & $p$-value (two-tailed) & 146 \\
\hline OID1 <- IMAG_DISC & 0.82 & 0.03 & 25.22 & 0.00 & \\
\hline OID2 <- IMAG_DISC & 0.85 & 0.03 & 25.48 & 0.00 & \\
\hline OID3 <- IMAG_DISC & 0.87 & 0.02 & 45.51 & 0.00 & 653 \\
\hline OID4 <- IMAG_DISC & 0.89 & 0.02 & 41.87 & 0.00 & \\
\hline OID5 <- IMAG_DISC & 0.87 & 0.02 & 36.91 & 0.00 & \\
\hline CS1 <- CREAT_SUG & 0.77 & 0.04 & 21.46 & 0.00 & \\
\hline CS2 <- CREAT_SUG & 0.85 & 0.03 & 28.68 & 0.00 & \\
\hline CS3 <- CREAT_SUG & 0.89 & 0.02 & 51.05 & 0.00 & \\
\hline CS4 <- CREAT_SUG & 0.84 & 0.03 & 29.00 & 0.00 & \\
\hline CS5 <- CREAT_SUG & 0.86 & 0.03 & 30.49 & 0.00 & \\
\hline CC1<-COOP_COL & 0.83 & 0.04 & 19.30 & 0.00 & \\
\hline $\mathrm{CC} 2<-\mathrm{COOP} \_\mathrm{COL}$ & 0.62 & 0.07 & 9.09 & 0.00 & \\
\hline CC3 <- COOP_COL & 0.78 & 0.07 & 11.46 & 0.00 & \\
\hline CC4<-COOP_COL & 0.87 & 0.02 & 37.27 & 0.00 & \\
\hline RS1 <- REC\&SEL & 0.67 & 0.06 & 11.41 & 0.00 & \\
\hline RS22<- REC\&SEL & 0.74 & 0.04 & 17.18 & 0.00 & \\
\hline RS33 <- REC\&SEL & 0.68 & 0.05 & 13.15 & 0.00 & \\
\hline RS4 <- REC\&SEL & 0.70 & 0.06 & 12.19 & 0.00 & \\
\hline RS5 <- REC\&SEL & 0.80 & 0.03 & 26.72 & 0.00 & \\
\hline RS6 <- REC\&SEL & 0.65 & 0.06 & 10.65 & 0.00 & \\
\hline IN1 <- ENVOLV & 0.68 & 0.05 & 14.95 & 0.00 & \\
\hline IN2 <- ENVOLV & 0.75 & 0.04 & 18.01 & 0.00 & \\
\hline IN3 <- ENVOLV & 0.75 & 0.04 & 20.51 & 0.00 & \\
\hline IN4 <- ENVOLV & 0.85 & 0.02 & 35.92 & 0.00 & \\
\hline IN5 <- ENVOLV & 0.77 & 0.04 & 21.19 & 0.00 & \\
\hline IN6 <- INVOLV & 0.58 & 0.06 & 9.83 & 0.00 & \\
\hline IN7 <- INVOLV & 0.80 & 0.03 & 27.01 & 0.00 & \\
\hline IN8 <- INVOLV & 0.74 & 0.04 & 19.24 & 0.00 & \\
\hline IN9 <- INVOLV & 0.73 & 0.04 & 17.98 & 0.00 & \\
\hline IN10 <- INVOLV & 0.64 & 0.06 & 10.89 & 0.00 & \\
\hline IN11 <- INVOLV & 0.71 & 0.04 & 18.78 & 0.00 & \\
\hline T\&D1 <- TRAIN\&DEV & 0.79 & 0.03 & 27.08 & 0.00 & \\
\hline T\&D2 <- TRAIN\&DEV & 0.75 & 0.04 & 19.79 & 0.00 & \\
\hline T\&D3 <- TRAIN\&DEV & 0.81 & 0.03 & 23.89 & 0.00 & \\
\hline T\&D4 <- TRAIN\&DEV & 0.82 & 0.04 & 22.98 & 0.00 & \\
\hline T\&D5 <- TRAIN\&DEV & 0.72 & 0.05 & 14.64 & 0.00 & \\
\hline T\&D6 <- TRAIN $\&$ DEV & 0.75 & 0.04 & 17.34 & 0.00 & \\
\hline WC1 <- WORK_COND & 0.75 & 0.04 & 19.00 & 0.00 & \\
\hline WC2 $<-$ WORK_COND & 0.62 & 0.07 & 9.11 & 0.00 & \\
\hline WC3 <- WORK_COND & 0.74 & 0.05 & 14.94 & 0.00 & \\
\hline WC4 <- WORK_COND & 0.83 & 0.03 & 31.99 & 0.00 & \\
\hline PE1 <- PE.EVE\&COMP & 0.85 & 0.03 & 29.23 & 0.00 & \\
\hline PE2 <- PE.EVE\&COMP & 0.82 & 0.03 & 24.65 & 0.00 & \\
\hline PE3 <- PE.EVE\&COMP & 0.87 & 0.03 & 32.79 & 0.00 & \\
\hline PE4 <- PE.EVE\&COMP & 0.87 & 0.02 & 38.82 & 0.00 & \\
\hline PE5 <- PE.EVE\&COMP & 0.85 & 0.03 & 32.23 & 0.00 & \\
\hline R\&R1 <- REM\&REW & 0.67 & 0.06 & 12.24 & 0.00 & \\
\hline R\&R2 <- REM\&REW & 0.79 & 0.04 & 21.63 & 0.00 & \\
\hline R\&R3 <- REM\&REW & 0.80 & 0.03 & 25.28 & 0.00 & \\
\hline R\&R4 <- REM\&REW & 0.83 & 0.02 & 33.68 & 0.00 & \\
\hline R\&R5 <- REM\&REW & 0.70 & 0.05 & 13.00 & 0.00 & \\
\hline
\end{tabular}

